\title{
ПІДВИЩЕННЯ РІВНЯ ІНФОРМАЦІЙНОГО ЗАБЕЗПЕЧЕННЯ ОХОРОНИ ЗДОРОВ'Я ЯК СКЛАДОВОЇ ПОБУДОВИ ІНФОРМАЦІЙНОЇ СТРАТЕГІї КОМУНІКАЦІЙНОї ДІЯЛЬНОСТІ ГАЛУЗІ
}

\author{
ДУ «Український інститут стратегічних досліджень МОЗ України», м. Київ
}

\begin{abstract}
Мета - висвітлити загальні принципи підвищення рівня інформаційного забезпечення як складової побудови інсрормаційної стратегії комунікаційної діяльності в охороні здоров'я.

Матеріали і методи: аналітичний, бібліосемантичний, метод системного підходу.

Результати. Аналіз інформаційно-комунікаційних технологій, що застосовуються в охороні здоров'я України, виявив недосконалість інформаційно-комунікаційної політики, спрямованої на роз'яснення мети, завдань та очікуваних результатів діяльності галузі охорони здоров'я, неадекватну і недостатню поінформованість населення, медичних працівників та управлінців галузі охорони здоров'я різних рівнів.

Висновки. Обґрунтовано орієнтовні загальні принципи підвищення рівня інорормаційного забезпечення як невід'ємної складової побудови інформаційної стратегії комунікаційної діяльності в охороні здоров'я України.
\end{abstract}

КЛЮчОВІ СЛОВА: інформаційне забезпечення, охорона здоров'я, комунікаційна діяльність.

Створення інорормаційного суспільства (інорормаційної цивілізації) $€$ необхідним чинником інтеграції України до світових інформаційних систем та її входження до Європейського Союзу. Інформаційне суспільство визначається зростанням ролі інорормації у соціальних відносинах, обробка та використання якої стає головним чинником еорективної діяльності.

Дослідженню різних видів інфрормації, визначенню її ролі присвячено багато праць зарубіжних вчених [1;5;11;12] з теорії обробки інорормації, методології і методики створення різних інфрормаційних систем, у тому числі медичного призначення.

Проблемі інформаційного забезпечення охорони здоров'я присвячено ряд робіт вітчизняних соціальних гігієністів та організаторів охорони здоров'я України [2-4;6-10].

Мета роботи - висвітлити загальні принципи підвищення рівня інорормаційного забезпечення як складової побудови інфрормаційної стратегії комунікаційної діяльності в охороні здоров'я.

Матеріали і методи: аналітичний, бібліосемантичний, метод системного підходу.

Результати дослідження та їх обговорення. Необхідність змін в інформаційному забезпеченні медичної галузі сьогодні обумовлена наступними причинами:

- децентралізацією управління системою охорони здоров'я та впровадженням економічних методів управління;

- розвитком ринкових відносин у галузі охорони здоров'я 3 опануванням нових функцій, які пов'язані з маркетингом (вивченням попиту на медичні послуги і фрормуванням ринку останніх) та ціноутворенням;

\footnotetext{
(с) Є.М. Кривенко, О.Р. Ситенко, 2015
}

- необхідністю розвитку медико-економічної статистики та медико-економічного аналізу;

- реструктуризацією первинної, вторинної та третинної медичної допомоги, для аналізу якої необхідно передбачити розподіл статистичних даних на зазначених рівнях;

- рефрормуванням первинної медико-санітарної допомоги на засадах сімейної медицини;

- підготовкою переходу галузі та її медикостатистичної служби до страхової медицини;

- фрормуванням єдиного медичного та відповідного інфрормаційного простору з включенням у нього медичних закладів іншої відомчої приналежності та різних фрорм власності;

- інорорматизацією охорони здоров'я.

Здійснення державою заходів із реформування охорони здоров'я показало гостру необхідність коригування системи взаємодії з населенням, а також проведення освітніх робіт з фахівцями в галузі охорони здоров'я. Встановлення дієвого зв'язку між керивними органами держави, установами охорони здоров'я і населенням, розробка ефективної комунікаційної стратегії допоможе істотно підвищити ступінь поінформованості людей щодо проведених реформ і тим самим різко знизити рівень негативної реакції і кількість непередбачених та, відповідно, слабко- і неконтрольованих ситуацій у сорері удосконалення охорони здоров'я.

У таблиці відображено основні шляхи розповсюдження інфрормації через ЗМІ (як головного засобу комунікацій 3 населенням) та основні групи її споживачів. Цільовими аудиторіями інфрормаційного впливу щодо змін у галузі $€$ усі категорії громадян та фрахівці у сорері охорони здоров'я.

Пропозиції з організації тих чи інших заходів мають ґрунтуватися на результатах аналізу про- 
Таблиця. Основні шляхи розповсюдження інформації через 3МІ

\begin{tabular}{|l|l|l|}
\hline \multicolumn{1}{|c|}{ ЗмІ } & \multicolumn{1}{|c|}{ Група цільового впливу } & \multicolumn{1}{c|}{ Зміст матеріалу } \\
\hline $\begin{array}{l}\text { Загальні друковані } \\
\text { змІ }\end{array}$ & $\begin{array}{l}\text { Пенсіонери, особи пра- } \\
\text { цездатного віку }\end{array}$ & $\begin{array}{l}\text { Підготовка матеріалів за попередньо заданими читачами } \\
\text { питаннями }\end{array}$ \\
\hline Телебачення & Усі вікові групи & $\begin{array}{l}\text { Рубрика у програмі, мета якої - просвітницька діяльність щодо } \\
\text { реалізації ресорм і поточних змін }\end{array}$ \\
\hline $\begin{array}{l}\text { Ооріційні сторінки } \\
\text { органів влади в } \\
\text { мережі Інтернет }\end{array}$ & $\begin{array}{l}\text { Спеціалісти системи } \\
\text { охорони здоров'я, } \\
\text { молодь та особи серед- } \\
\text { нього віку }\end{array}$ & $\begin{array}{l}\text { Основна інсорорація, пов'язана з проведеними ресормами; } \\
\text { публікація нововведень, змін і доповнень у нормативних актах; } \\
\text { відеження динаміки змін у громадській думці. } \\
\text { Оновлення - за необхідності }\end{array}$ \\
\hline Радіо & $\begin{array}{l}\text { Пенсіонери, особи стар- } \\
\text { шого віку }\end{array}$ & $\begin{array}{l}\text { Цикл передач і «прямих ліній» за участю фрахівців за пробле- } \\
\text { матикою }\end{array}$ \\
\hline
\end{tabular}

ведених досліджень щодо обізнаності населення країни 3 питань реформування системи охорони здоров'я та коригуватися залежно від громадського відгуку (обов'язкове дотримання принципу «зворотного зв'язку»).

На сучасному етапі в суспільстві існує ряд усталених думок, що перешкоджають успішній реалізації реформ охорони здоров'я, наприклад:

- усі перетворення, що проводяться державою, не несуть позитивних змін, а спрямовані лише на те, щоб знизити і без того невисокий рівень життя населення;

- державні медичні установи надають послуги дуже низької якості;

- висока вартість якісних послуг.

Попри те, що спростування даних стереотипів не $€$ основним завданням, вважаємо важливим покращувати імідж системи охорони здоров'я та за можливості вести роботу і в цьому напрямку, тим більше, що подібні думки, поширені серед значної кількості населення, перешкоджають реалізації рефрорм в країні. При цьому виділяються ключові напрямки взаємодії: забезпечення контакту 3 населенням і максимальне забезпечення його інфрормацією в галузі реформування системи охорони здоров'я країни, демонстрація реальної роботи та захисту інтересів громадян і медичних працівників.

У зв'язку з тим, що аудиторія громадян дуже різноманітна 3 точки зору вікових характеристик, освіти, сфрер діяльності тощо, очевидно, що охоплення використовуваних медіаканалів повинне бути максимальним (радіо, телебачення, друковані видання, залучення Інтернет-ресурсів тощо).

3 метою підвищення рівня інформаційного забезпечення охорони здоров'я як складової побудови інорормаційної стратегії комунікаційної діяльності галузі можна виділити загальні цілі і завдання:

- підвищення рівня інформованості населення та медичних працівників з питань діяльності галузі охорони здоров'я;

- удосконалення системи взаємодії між управлінцями охорони здоров'я, лікарями/медичними працівниками і громадянами;

- створення позитивного іміджу проведених в країні перетворень;

- усунення невдоволення населення 3 приводу ресрорм охорони здоров'я;

- економія часу фахівців охорони здоров'я, змушених сьогодні не тільки виконувати свої профе- сійні фрункції, але й відповідати на велику кількість питань, що задаються громадянами, схвильованими проведенням реформ.

Інформаційна стратегія має включати комплекс наступних заходів:

- створення в мережі Інтернет спеціалізованого порталу із неупередженого та об'єктивного висвітлення діяльності галузі охорони здоров'я;

- розробка і випуск телевізійної програми, присвяченої організації та діяльності системи охорони здоров'я і періодичне включення в неї сюжетів про хід рефрормування охорони здоров'я;

- випуск періодичних публікацій у друкованих 3МІ, а також серії сюжетів по радіо і телебаченню, присвячених даній проблематиці і поточним змінам;

- удосконалення системи роботи «Гарячих ліній» не тільки $з$ метою надання населенню інфрормації, але й для отримання необхідних відомостей про ступінь інформованості населення 3 питань проведених в країні перетворень. За результатами аналізу отриманих даних фрахівцями повинно проводитися коригування обсягу і змісту діяльності;

- організація наочної інорормації на окремих стендах в 303, а також в аптеках - на видному і зручному для читання місці, що значно зменшить ступінь схвильованості і підозрілості громадян, створить умови для ознайомлення з правилами законного отримання інформації та захисту своїх прав.

Результати проведеної роботи повинні постійно моніторуватися, а її ефективність має визначатися за наступними основними напрямками:

1. Регулярне вивчення громадської думки, що дозволить відстежувати динаміку змін соціальноекономічної ситуації в регіоні та певною мірою оцінити результативність інфрормаційно-просвітницької діяльності.

2. Підготовка відповідних звітів та аналітичних матеріалів за результатами моніторингу висвітлення даних питань у $3 \mathrm{MI}$.

3. Аналіз питань, що задаються по телефонах «гарячої лінії», що дозволяє оцінити рівень інформованості населення щодо змін, які відбуваються в країні та у галузі охорони здоров'я.

4. Здатність діючої в галузі охорони здоров'я системи інфрормаціного забезпечення адекватно та своєчасно реагувати як на зміни, що відбуваються в галузі, так і на інтереси медичної спільноти та громадськості як основного споживача інорормації. 
Інфрормаційне забезпечення, інорорматизація та удосконалення державного управління перебувають у тісному взаємозв'язку і взаємообумовленості. 3 одного боку, вони обумовлюють зростання складності процесів удосконалення фрорм і методів управління, з іншого - внаслідок розвитку науки й техніки - виникають нові ефективні можливості удосконалення управління завдяки подальшому розвитку теорії організації складних систем, теорії управління на основі використання нових комп'ютерних інформаційних технологій. Процес оптимізації інфрормаційного забезпечення багато в чому залежить від якісного рівня управління відповідними соціальними системами: людиною, громадою, державою, суспільством.

\section{Висновки}

Недосконалість інфрормаційно-комунікаційної політики, спрямованої на роз'яснення мети, завдань та очікуваних результатів діяльності галузі охорони здоров'я, неадекватна і недостатня поінформованість населення, медичних працівників та управлінців галузі охорони здоров'я різних рівнів обумовлюють необхідність підвищення рівня інформаційного забезпечення як невід'ємної складової побудови інфрормаційної стратегії комунікаційної діяльності в охороні здоров'я України.

Відмінною рисою вітчизняної охорони здоров'я $€$ те, що державна медицина має негативний імідж, що, однак, не відображає реального стану справ (досить висока кваліфрікація фрахівців, використання сучасного обладнання та підхід до роботи 3 урахуванням інтересів пацієнтів). Дана проблема вимагає спеціального розгляду, оскільки є непереборною перешкодою в успішному функціонуванні та подальшому розвитку всієї системи вітчизняної охорони здоров'я.

Діяльність галузі охорони здоров'я наразі потребує розуміння і позитивної оцінки у суспільстві, що зумовлює необхідність залучення ЗМІ для висвітлення роботи державних органів та закладів охорони здоров'я і формування об'єктивної громадської думки.

Процес побудови рівня інфрормаційного забезпечення охорони здоров'я як складової побудови інфрормаційної стратегії комунікаційної діяльності галузі повинен бути достатньо гнучким та націленим на дотримання принципу «зворотного зв'язку».

Основні принципи комунікації, які необхідно забезпечити для досягнення мети інформаційнокомунікативної політики: створення та підтримка довіри з боку громадськості; своєчасність надання інформації; інформаційна відкритість та прозорість; адаптація інформації до поглядів та загальної думки, яка вже сорормувалася.

Перспективи подальших досліджень полягають у подальшому вивченні принципів формування та впровадження елементів комунікаційних технологій в галузі охорони здоров'я України.

\section{Список літератури}

1. Ключко Н. В. О понятии «управление информацией» [Электронный документ] / Н. В. Ключко. - Режим доступа : http://www.cognitive.ru/innovation/sbornic3/index. htm. - Заглавие с экрана.

2. Коваленко О. С. Застосування інформаційних технологій в охороні здоров'я / О. С. Коваленко // Управління підприємницькою діяльністю в галузі охорони здоров'я : [колективна монографія] ; за ред. О. В. Баєвої, І. М. Солоненко. - Київ : МАУП, 2007. - С. 135-157.

3. Королько В. Г. Зв'язки з громадськістю. Наукові основи, методика, практика / В. Г. Королько, О. В. Некрасова. 3-тє вид., доп. і перероб. - Київ : ВД «Києво-Могилянська академія», 2009. - 831 с.

4. Кузнецов О. В. Технологія використання інфрормації для коригування управлінських рішень [Електронний документ] / О. В. Кузнецов. - Режим доступу : http://www.mndc.naiau.kiev.ua. - Заголовок з екрану.

5. Малахова Н. Г. Маркетинг в здравоохранении / Н. Г. Малахова. - Ростов-на-Дону : Феникс, 2010. - 224 с.

6. Проблеми інорорматизації та управління : збірка наук. пр. - Вип. 4 (44). - Київ : НАУ, 2013. - 110 с.

7. Руденко С. В. Роль системы информатизации здравоохранения в повышении качества медицинских услуг / С. В. Руденко, Н. В. Романенко // Науковий вісн. міжнар. гуманітарного ун-ту. - 2010. - № 1. - С. 95-99.

8. Управління організацією як процес цілеспрямованого перетворення управлінської інформації [Електронний документ]. - Режим доступу : http://ruh.znaimo.com.ua/index-18115.html. - Заголовок з екрану.

9. Чабан О. Огляд світової практики щодо впровадження медичних інфрормаційних систем та проблеми створення єдиного медико-інформаційного простору / О. Чабан, О. Бойко // Комп'ютерні науки та інформаційні технології : вісн. нац. ун-ту. - Львів : Львівська політехніка, 2013. - № 771. - С. 365-370.

10. Череп А. В. Стратегічне планування і управління / А. В. Череп, А. В. Сучков. - Київ : Кондор, 2011. - 334 с.

11. Enabling Medication Management Through Health Information Technology: Evidence Report / Technology Assessment. - Hamilton: McMaster Evidence-based Practice Center, 2011. - 951 p.

12. Schwarze J. Organizational aspects of information management / J. Schwarze // Inf. Manag. Pract. and Educ. : Int. Semin., Budapest, 24-27 Apr., 2010 : Proc. Budapest, 2010. - Vol. 2. - P. 402-409.

ПОВЫШЕНИЕ УРОВНЯ ИНФОРМАЦИОННОГО ОБЕСПЕЧЕНИЯ КАК СОСТАВЛЯЮЩЕЙ ПОСТРОЕНИЯ ИНФОРМАЦИОННОЙ СТРАТЕГИИ КОММУНИКАЦИОННОЙ ДЕЯТЕЛЬНОСТИ В ЗДРАВООХРАНЕНИИ УКРАИНЫ

Е.Н. Кривенко, Е.Р. Ситенко

ГУ «Украинский институт стратегических исследований МЗ Украины», г. Киев

Цель - осветить общие принципы повышения уровня информационного обеспечения как составляющей построения иноормационной стратегии коммуникационной деятельности в здравоохранении. 
Материалы и методы: аналитический, библиосемантический, метод системного подхода.

Результаты. Анализ инорормационно-коммуникационных технологий, применяемых в здравоохранении Украины, обнаружил несовершенство инорормационно-коммуникационной политики, направленной на разъяснение целей, задач и ожидаемых результатов деятельности отрасли здравоохранения, неадекватную и недостаточную осведомленность населения, медицинских работников и управленцев здравоохранения разных уровней.

Выводы. Обоснованы ориентировочные общие принципы повышения уровня инфрормационного обеспечения как неотъемлемой составляющей построения инорормационной стратегии коммуникационной деятельности в здравоохранении Украины.

КЛЮЧЕВЫЕ СЛОВА: информационное обеспечение, здравоохранение, коммуникационная деятельность.

\section{IMPROVED INFORMATION SUPPORT AS A PART OF BUILDING INFORMATION COMMUNICATION STRATEGY IN HEALTHCARE OF UKRAINE}

Ye.M. Kryvenko, O.R. Sytenko

PE "Ukrainian Institute of Strategic Researches MHC of Ukraine", Kyiv

Purpose - to illuminate general principles of increasing the level of information security as a part of building information communication strategy in health care.

Materials and methods: analytical, bibliosemantical, the method of systematic approach.

Results. Analysis of the information and communication technologies used in healthcare of Ukraine, found imperfect information and communication policy aimed at clarifying the goals, objectives and performance expectations of health, inadequate and insufficient awareness, health professionals and health managers at different levels.

Conclusions. Reasonably approximate the general principles of increasing the level of information security as an integral part of building the information communication strategy in healthcare.

KEY WORDS: information security Healthcare communication activities.

Рукопис надійшов до редакції 20.11.2015 p.

\section{Відомості про авторів:}

Ситенко Олена Ростиславівна - к.мед.н., старший науковий співробітник ДУ «Український інститут стратегічних досліджень МО3 України», завідувач науково-організаційного відділу; тел.: +38(044) 576-41-09.

Кривенко Євгеній Миколайович - завідувач відділу інорорматизації охорони здоров'я ДУ «Український інститут стратегічних досліджень МО3 України»; тел.: +38(044) 576-41-16. 